HETEROCYCLES, Vol. 98, No. 1, 2019, pp. 3 - 18. @ 2019 The Japan Institute of Heterocyclic Chemistry

Received, 15th August, 2018, Accepted, 2nd November, 2018, Published online, 18th December, 2018

DOI: 10.3987/REV-18-895

\title{
RECENT ADVANCEMENTS IN THE SYNTHESIS OF HALF-ESTERS AND THEIR APPLICATIONS
}

\section{Jianjun Shi and Satomi Niwayama*}

Division of Sustainable and Environmental Engineering, Graduate School of Engineering, Muroran Institute of Technology, 27-1, Mizumoto-cho, Muroran, Hokkaido, 050-8585, Japan. E-mail: niwayama@mmm.muroran-it.ac.jp

\begin{abstract}
Half-esters are important building blocks for the synthesis of pharmaceuticals, polymers and natural products. Therefore, synthetic methodologies for both chiral and racemic half-esters have been actively investigated for decades. This short review summarizes recent progress in the synthesis of half-esters and their applications including the studies from our laboratories.
\end{abstract}

\section{Contents:}

1. Introduction

2. Synthesis and Application of Half-Esters

3. Conclusions

\section{INTRODUCTION}

Half-esters have structures with a carboxyl group and an ester group in the same molecule (Scheme 1) and have been versatile building blocks for construction of a variety of classes of significant compounds such as polymers, dendrimers, and pharmaceuticals. ${ }^{1}$ As described in this article, half-esters can also be converted to heterocyclic compounds by introduction of nitrogen atoms, for example, via Curtius rearrangement. The development of methodologies for their synthesis has thus been significant.

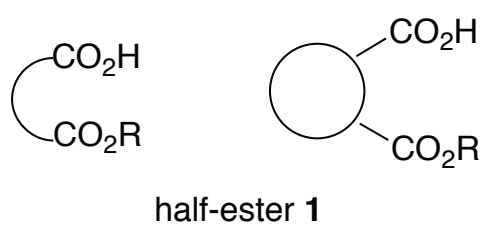

Scheme 1. Structure of haf-esters 
Typically, the synthetic methods for half-esters can be classified into 1) ring opening of cyclic anhydrides, 2) enzymatic hydrolysis of diesters, 3) monohydrolysis of diesters, and 4) other methods. This review focuses on advancements in the synthesis of half-esters, including work from our laboratories, and details about applications of half-esters in the last few decades.

\section{SYNTHESIS AND APPLICATION OF HALF-ESTERS}

1) Ring opening of cyclic anhydrides

In many cases, ring opening reactions of cyclic anhydrides with alkoxides or with alcohols and acids produce the corresponding half-esters with variable yields depending on the conditions, and therefore this method has been popular for decades (Scheme 2). Both racemic and enantiomerically enriched half-esters can be synthesized depending on the catalyst applied. These catalysts are exemplified as inorganic acids, ionic liquids, and organic catalysts such as cinchona alkaloids.

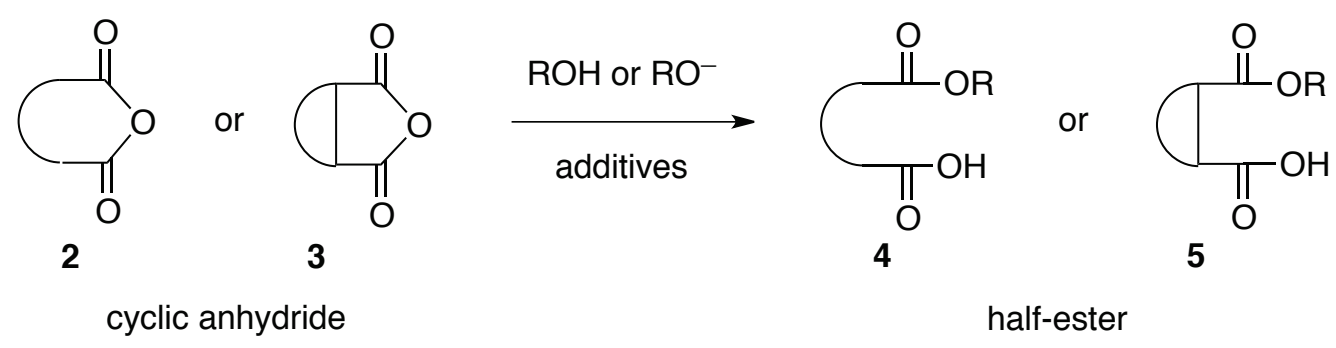

Scheme 2. Synthesis of half-esters from cyclic anhydrides

Among the most classical ring opening reactions is refluxing in an alcohol. ${ }^{2}$ Use of a Lewis acid such as $\mathrm{BF}_{3} \cdot \mathrm{OEt}_{2}$ tends to accelerate the reactions and therefore such reactions have been studied lately.

For example, Sabitha et al. systematically examined many kinds of starting anhydrides and several Lewis acids and found that $\mathrm{BF}_{3} \cdot \mathrm{OEt}_{2}$ acts as the most efficient Lewis acid catalyst among those they studied under mild conditions at room temperature in $\mathrm{MeOH}$ and $\mathrm{EtOH}$, affording the corresponding half-esters in high yields within an hour. ${ }^{3}$

The asymmetric alcoholysis of symmetric cyclic anhydrides with cinchona alkaloids, producing enantiomerically enriched half-esters, has been extensively studied by many researchers such as Oda $e t$ al., ${ }^{4}$ Aitken et al., ${ }^{5}$ Bolm et al., ${ }^{6}$ Deng et al., ${ }^{7}$ Furukawa et al., ${ }^{8}$ Carloni et al. ${ }^{9}$ Han et al., ${ }^{10}$ and Chin and Song et al. ${ }^{11}$ as in Table 1. The mechanistic insight into asymmetric induction in these alcoholysis reactions of symmetric cyclic anhydrides has also been offered based on sterically favorable alignments of the functional groups in the transition state obtained by modeling studies. 
Table 1. Asymmetric alcoholysis of symmetric cyclic anhydrides with cinchona alkaloids

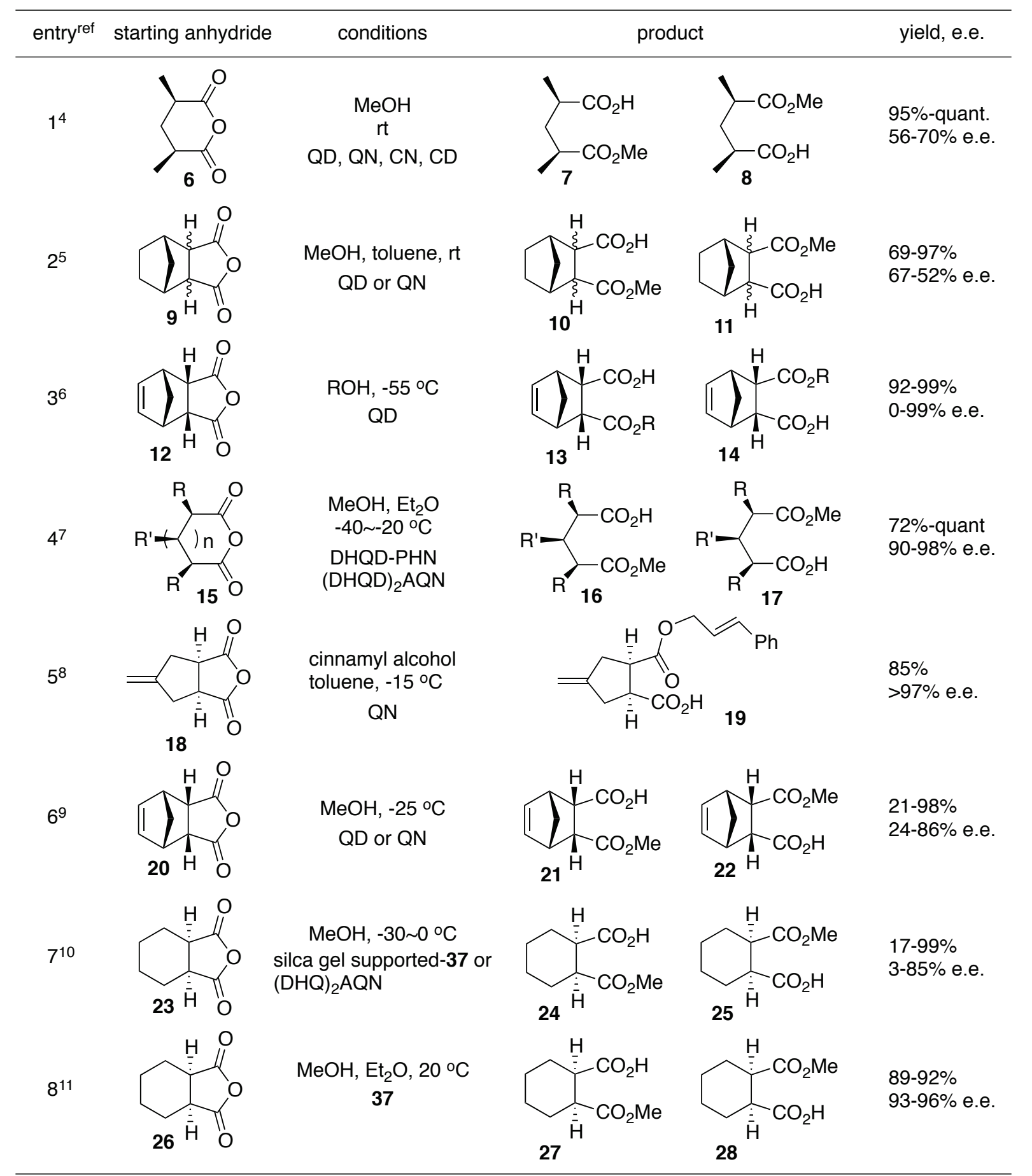<smiles>[R]c1ccc2nccc([C@@H](O)N3C4CCC3CC([R])C4)c2c1</smiles>

29: cinchonidine $(C D): \mathrm{R}=\mathrm{H}, \mathrm{R}^{\prime}=\mathrm{vin} y \mathrm{l}$ 30: quinine $(\mathrm{QN})$ : $\mathrm{R}=\mathrm{OMe}, \mathrm{R}^{\prime}=\mathrm{vinyl} \quad 34$ : dihydroquinidine $(\mathrm{DHQD})$ : $\mathrm{R}=\mathrm{OMe}, \mathrm{R}^{\prime}=\mathrm{Et}$ 31: dihydroquinine $(\mathrm{DHQ})$ : $\mathrm{R}=\mathrm{OMe}, \mathrm{R}^{\prime}=\mathrm{Et}$<smiles>[R]c1ccc2nccc([C@H]3CC4CCN(C3)C4[R])c2c1</smiles>

32: cinchonine $(\mathrm{CN})$ : $\mathrm{R}=\mathrm{H}, \mathrm{R}^{\prime}=\mathrm{vinyl}$ 33: quinidine (QD): $\mathrm{R}=\mathrm{OMe}, \mathrm{R}^{\prime}=\mathrm{vinyl}$ DQHD<smiles>Cc1cc2ccccc2c2ccccc12</smiles>

35: DHQD-PHN

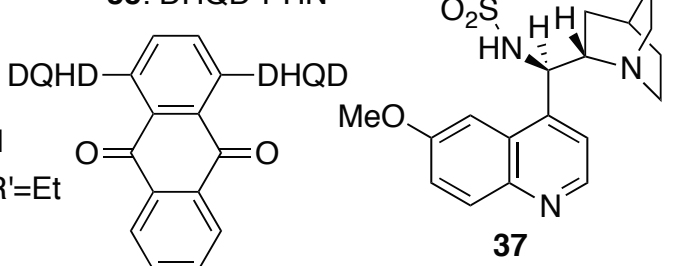

37

36: (DHQD) ${ }_{2} A Q N$ 
Dai et al. studied ring opening of cyclic anhydrides with Bronsted acidic ionic liquids and found that these were efficient recyclable catalysts which afford half-esters in short reaction times in good yields. ${ }^{12}$

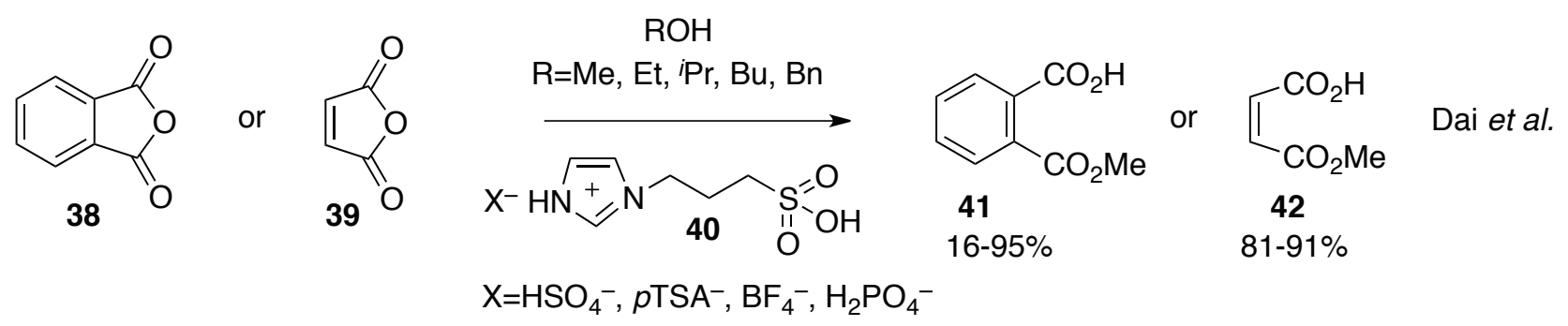

Scheme 3. Ring opening with Bronsted acidic ionic liquids by Dai et al.

Kim et al. applied half-esters obtained from ring openings of succinic anhydride derivatives with various fatty alcohols to improvement of the lubricities of diesel fuels ${ }^{13}$ (Scheme 4). They prepared a series of half-esters in two isomeric forms from various alkyl-substituted succinic acids in high yields (>97\%). The alkyl succinic acid half-esters produced contain carboxyl groups that interact with metals and ester groups, which allow contact with fuels, and therefore due to the delicate balance between these functional groups, these half-esters exhibit excellent lubricity performance as additives.

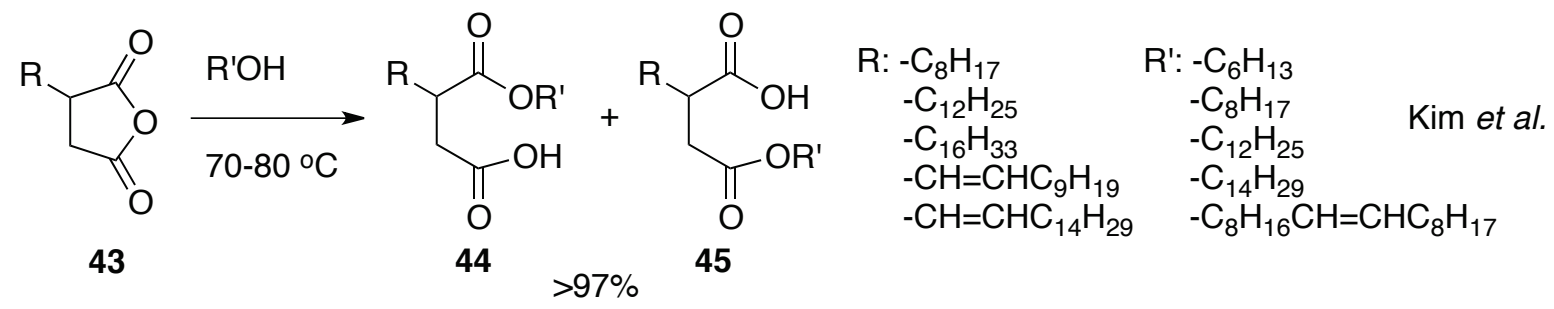

Scheme 4. Half-esters applied to improvement of the lubricities of diesel fuels by Kim et al.

The drawback of these ring-opening reactions is that they require anhydrous conditions often with a dry organic solvent such as toluene, benzene, ethers, or chloroform. These ring-opening reactions also require the stereochemistry of the formed cyclic half-esters to be cis.

Somewhat interesting cases are reported for ring opening of cyclic anhydrides with the use of enzymes, although enzymes are typically used for monohydrolysis of symmetric diesters in the context of the synthesis of half-esters as described below. Such reactions can be done in aqueous media. Barreiros et al. studied acylation of succinic anhydride in the presence of ionic liquids and racemic $(R, S)$-2-octanol catalyzed by immobilized Candida antarctica lipase B (CALB) (Scheme 5). The $(R)$-half-ester was obtained and optical resolution was achieved. ${ }^{14}$ 


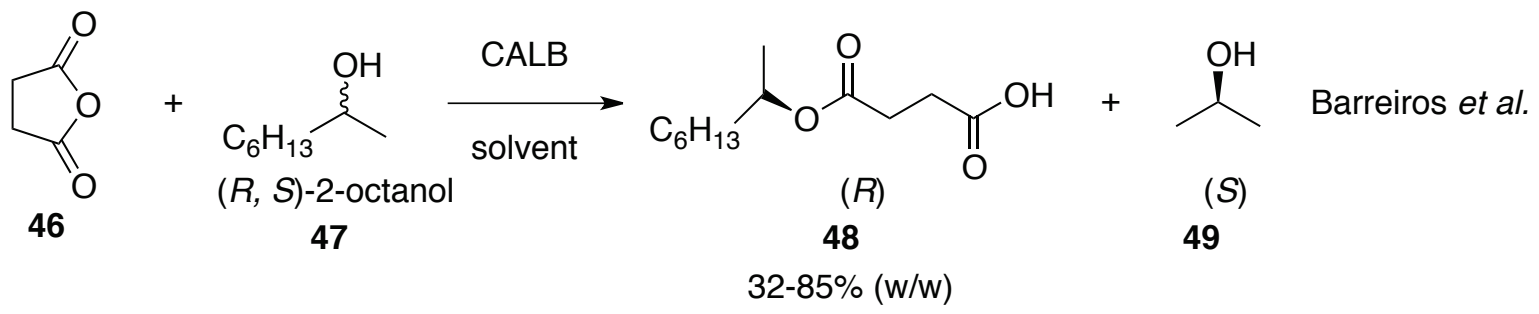

Scheme 5. Enzymatic ring opening of cyclic anhydrides by Barreiros et al.

2) Enzymatic methods

Enzymes have been widely applied to the preparation of half-esters, especially for monohydrolysis of diesters (Scheme 6). Among the most frequently employed enzymes are esterases ${ }^{15-23}$ and lipases ${ }^{24}$ for the hydrolysis of esters. The enzyme catalysts have broad substrate specificities, activities, and enantioselectivities. In particular, the enantioselective hydrolysis reactions of meso-diesters have frequently been catalyzed by esterases such as pig liver esterase, producing chiral half-esters.

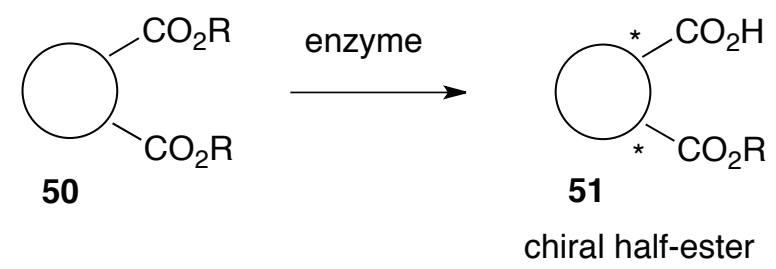

Scheme 6. Enzymatic monohydroysis

The drawback of these enzymatic monohydrolyses of diesters is that the mechanism is not understood, and therefore random screening is required. Nevertheless, symmetric diesters are generally inexpensively prepared on a large scale, and the formed half-esters are enantiomerically enriched. Therefore, these half-esters with high enantiomeric excesses have been applied to the synthesis of various natural products and pharmaceuticals, sometimes even on an industrial scale.

Ohno et al. developed one of the most pioneering studies using half-esters obtained by the monohydrolysis of symmetric diesters mostly with pig liver esterase. They applied several half-esters, 53,60 , and 63 (Scheme 7) to the total synthesis of a wide range of natural products and pharmaceuticals such as nucleosides,${ }^{15}$ (-)-fortamine,${ }^{16}$ and carbapenems ${ }^{17,18}$ including asparenomycin $\mathrm{C}$, thienamycin, and carbetimycin A. Nagao et al. reported the synthesis of (+)-carbacyclin, ${ }^{19}$ and $\mathrm{Yu}$ et al. reported the synthesis of paroxetine,$^{20}$ both starting from half-esters obtained by the monohydrolysis of symmetric diesters with pig liver esterase (Scheme 7). The latter is a well-known selective serotonin reuptake inhibitor produced by GlaxoSmithKline for the treatment of depression. 


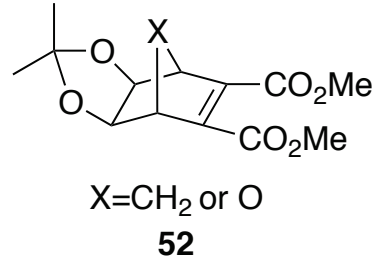

pig liver esterase

(PLE)<smiles>Nc1ncnc2c1ncn2C1C[C@H](O)[C@@H](O)[C@H](O)C1</smiles>

(-)-aristeromycin

54<smiles>Nc1ncnc2c1ncn2C1C=C(CO)C(O)C1O</smiles>

(-)-neplanocin

55<smiles>[X]C1C2C(C(=O)O)=C(C(=O)O)C1C1OC(C)(C)OC12</smiles>

53 $\mathrm{X}=\mathrm{CH}_{2}$ : quant, $80 \%$ e.e. $\mathrm{X}=\mathrm{O}: 96 \%, 77 \%$ e.e.

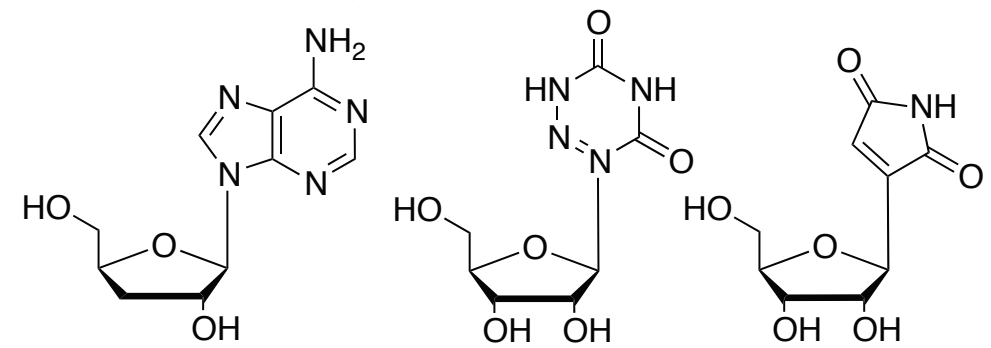

(-)-cordycepin

56 (-)-6-azapseudouridine (-)-showdomycin

57<smiles>COC(=O)C1CC=CCC1C(C)=O</smiles>

59 pig liver esterase

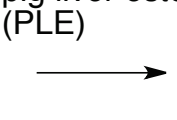<smiles>CC(=O)OC1CC=CCC1C(=O)O</smiles>

94-99\%, 85-99\% e.e.

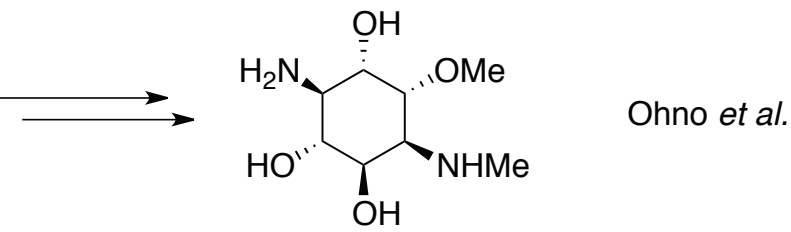

(-)-fortamine

pig liver esterase

61

$$
\mathrm{MeO}_{2} \mathrm{C} \widehat{\mathrm{NHCO}}_{2} \mathrm{CH}_{2} \mathrm{C}_{6} \mathrm{H}_{5}
$$

62<smiles>CCCCOC(=O)NC(CC(=O)O)CC(=O)OCc1ccccc1</smiles>

63 93\%, 93\% e.e.<smiles>CC(=O)NC=CSC1=C(C(=O)O)N2C(=O)C(=C(C)C)C2C1</smiles>

(-)-asparenomycin C

64<smiles>CC(O)[C@H]1C(=O)N2C(C(=O)O)=C(SCCN)C[C@H]12</smiles>

(+)-thienamycin

65<smiles>CC(C)(O)C1C(=O)N2C(C(=O)O)=C([SH](O)C=CNC(=O)O)CC12</smiles>

(-)-carpetimycin $\mathrm{A}$

66

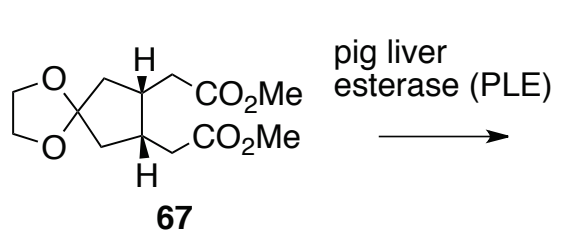

67<smiles>COC(=O)C1CC(C(=O)O)CC12CC(C(=O)O)CO2</smiles>

99\%, $94 \%$ e.e.

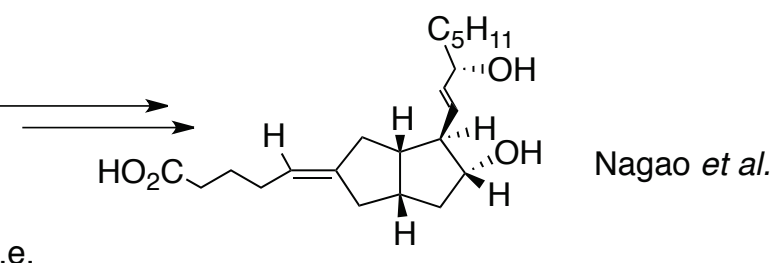

(+)-Carbacyclin 69<smiles>COCCC(CCOC)c1ccc(F)cc1</smiles>

70

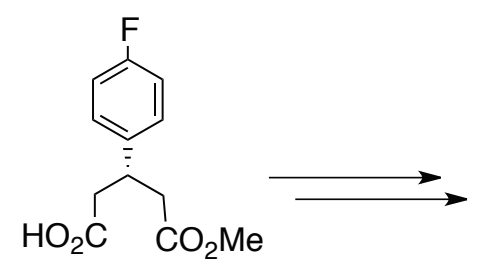

71

$86 \%$, $95 \%$ e.e.<smiles>Fc1ccc(C2CCNCC2COc2ccc3c(c2)OCO3)cc1</smiles>

Paroxetine
Yu et al.

Scheme 7. Application of half-esters obtained with pig liver esterase 
More recently, Back et al. ${ }^{21}$ and Materson et al..$^{22}$ performed the enantioselective synthesis of amino acid derivatives from the half-esters of malonic acid derivatives also obtained by pig liver esterase. Nakada et al. reported the synthesis of the intermediate for ent-kauranoids from the half-esters obtained by pig liver esterase monohydrolysis of a cyclohexane derivative (Scheme 8$).^{23}$

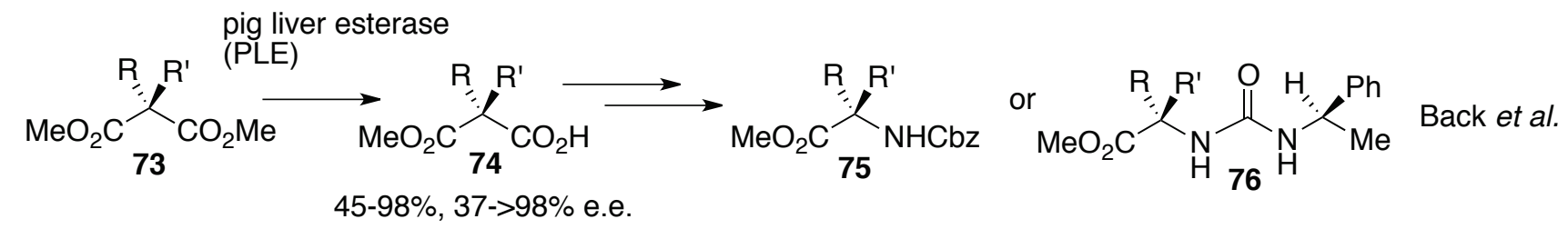

$R=$ larger substitutent; $R^{\prime}=$ smaller substituent

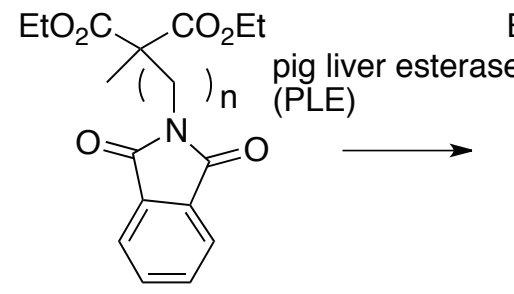

77

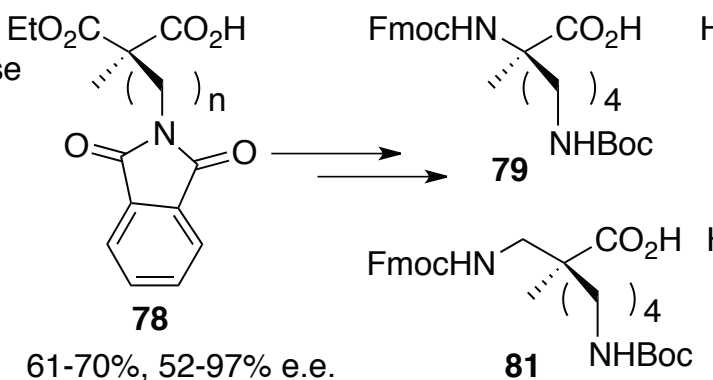

$61-70 \%, 52-97 \%$ e.e.

81

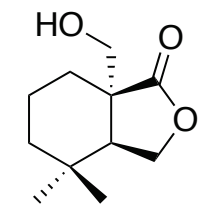

85

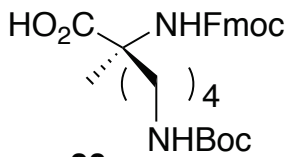

80 Masterson et al.

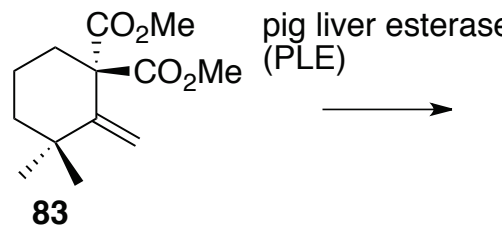

$97 \%$

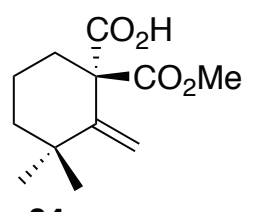

84

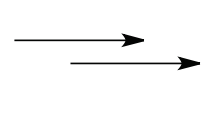

Nakada et al.

Scheme 8. Application of half-esters obtained with pig liver esterase

\section{3) Hydrolysis of esters}

Considering the uncontrolled outcomes, the monohydrolysis of symmetric diesters without an enzyme catalyst has been a rewarding task. Among the most commonly used methods about ester hydrolysis are saponification reactions, using a base such as $\mathrm{LiOH}, \mathrm{NaOH}$, and $\mathrm{KOH}$ in an alcohol. This method has been generally useful for the hydrolysis of a single ester into a carboxylic acid on a large scale at low cost. However, distinguishing two identical ester groups has been a more challenging task. The classical monosaponification of symmetric diesters tends to produce complex mixtures consisting of starting diesters, half-esters, and diacids in which both ester groups are hydrolyzed, and a small percentage of the corresponding half-esters. ${ }^{25}$ Many of these mixtures do not enable purification at the stage of monohydrolysis, and therefore crude half-esters are used for further steps without purification. For this reason, only a limited number of successful examples have been reported especially for diesters of malonic acid and their derivatives. ${ }^{26}$ 
Other bases such as those prepared from quaternary ammonium salts have sometimes been utilized for monohydrolysis of diesters. Yan et al. explored optimal conditions for the monohydrolysis of diethyl 2,6-dimethyl-4-aryl-4H-pyran-3,5-dicarboxylates using tetraethylammonium bromide, but the yields of the half-esters were modest (Scheme 9). ${ }^{27}$ The half-esters of diethyl 2,6-dimethyl-4-aryl-4H-pyran3,5-dicarboxylates are sometimes utilized in drug discovery.<smiles>CCOC(=O)C1=C(C)OC(C)=C(C(=O)OCC)C1c1ccccc1</smiles>

86<smiles>[R]OCCOC(=O)C1=C(C)OC(C)=C(C(=O)O)C1c1ccccc1</smiles>

87<smiles>CC1=C(C(=O)O)C(c2ccccc2)C(C(=O)O)=C(C)O1</smiles>

88

$20-69 \%$

$\mathrm{R}=\mathrm{H} ; p-\mathrm{Me} ; p-\mathrm{OMe}_{3} ; p-\mathrm{Cl} ; m-\mathrm{Cl} ; p-\mathrm{F} ; p-\mathrm{NO}_{2} ; m-\mathrm{NO}_{2} ; m-\mathrm{Br} ; m-\mathrm{NHCOMe} ; 2,3,4$-triOMe

Scheme 9. Monohydrolysis of diethyl 2,6-dimethyl-4-aryl-4H-pyran-3,5-dicarboxylates by Yan et al .

Sometimes acidic hydrolysis of $t$-butyl ester has also been combined for production of desirable half-esters (Scheme 10). ${ }^{28}$

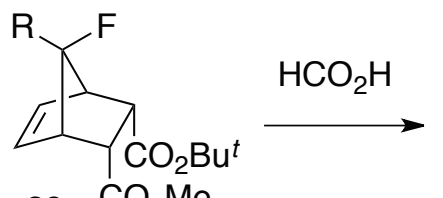

89

$\mathrm{R}=\mathrm{H}, \mathrm{F}$

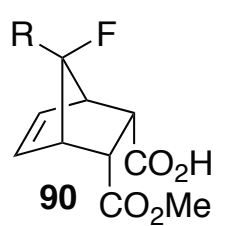

Frimer et al.

Scheme 10. Acidic hydrolysis of tert-butyl esters by Frimer et al.

However, Niwayama et al. reported a highly efficient and practical ester monohydrolysis of symmetric diesters (Scheme 11). ${ }^{29}$ This reaction employs an aqueous medium, in which aqueous $\mathrm{NaOH}$ or $\mathrm{KOH}$ is added to a symmetric diester that may be dissolved in a co-solvent such as THF, MeCN, or another polar aprotic co-solvent diluted at $0{ }^{\circ} \mathrm{C}$. This co-solvent may be unnecessary in certain cases. With this reaction, pure half-esters are obtained in high yields to near-quantitative yields, despite the fact that the statistically expected yield is a maximum of only 50\%. The procedures are simple, and the reaction mixtures are clean unlike the mixtures that result from classical saponification, and therefore the isolation and purification of the resultant half-esters after routine procedures is straightforward in all the cases tried thus far. Table 2 shows some examples. 


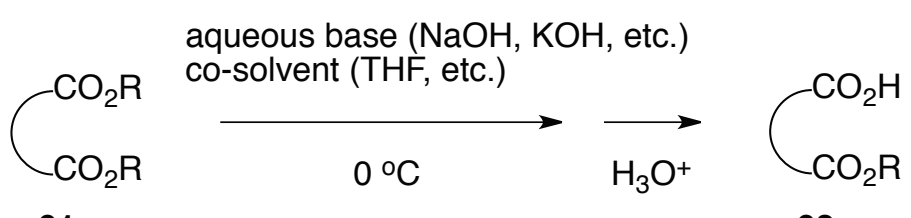

91

92

Scheme 11. Selective monohydrolysis of symmeric diesters by Niwayama et al.

Table 2. Some examples for selective monohydrolysis reported by Niwayama et al.

\begin{tabular}{|c|c|c|c|}
\hline entry & diester & product & yield $(\%)^{a}$ \\
\hline 1 & $\mathrm{MeO}_{2} \mathrm{C} \underset{93}{\sim} \mathrm{CO}_{2} \mathrm{Me}$ & $\mathrm{HO}_{2} \mathrm{C} \underset{94}{\sim \mathrm{CO}_{2} \mathrm{Me}}$ & $80 \%$ \\
\hline 2 & $\mathrm{MeO}_{2} \mathrm{C} \underset{95}{\mathrm{CO}_{2} \mathrm{Me}}$ & $\underset{96}{\mathrm{HO}_{2} \mathrm{C} \rightleftharpoons \mathrm{CO}_{2} \mathrm{Me}}$ & $79 \%$ \\
\hline 3 & $\mathrm{MeO}_{2} \mathrm{C}_{97}^{-1} \mathrm{CO}_{2} \mathrm{Me}$ & ${ }_{98}^{\mathrm{HO}_{2} \mathrm{C}}{ }_{98}^{-1} \mathrm{CO}_{2} \mathrm{Me}$ & $95 \% \mathrm{~b}$ \\
\hline 4 & $\begin{array}{l}-\mathrm{CO}_{2} \mathrm{Me} \\
-\mathrm{CO}_{2} \mathrm{Me} \\
99\end{array}$ & $\begin{array}{l}\mathbb{Z} \mathrm{CO}_{2} \mathrm{Me} \\
100\end{array}$ & $>99 \%$ \\
\hline 5 & $\begin{array}{l}\mathbb{Z}_{\mathrm{CO}_{2} \mathrm{Me}}^{\mathrm{CO}_{2} \mathrm{Me}} \\
101\end{array}$ & $\begin{array}{l}\mathbb{I}_{\mathrm{CO}_{2} \mathrm{Me}}^{\mathrm{CO}_{2} \mathrm{H}} \\
102\end{array}$ & $>99 \%$ \\
\hline 6 & $\begin{array}{l}\mathrm{IIO}_{2} \mathrm{CO}_{2} \mathrm{Me} \\
{ }_{103}\end{array}$ & ${ }_{104} \mathrm{CO}_{2} \mathrm{Me}$ & $>99 \%$ \\
\hline 7 & $\mathrm{CO}_{2} \mathrm{Et}$ & $\mathrm{CO}_{2} \mathrm{Et}$ & $94 \%$ \\
\hline 8 & $\begin{array}{l}\mathbb{T}_{\mathrm{CO}_{2} \mathrm{Et}}^{\mathrm{CO}_{2} \mathrm{Et}} \\
107\end{array}$ & $\begin{array}{l}\mathbb{2}_{\mathrm{CO}_{2} \mathrm{Et}}^{\mathrm{CO}_{2} \mathrm{H}} \\
108\end{array}$ & $>99 \%$ \\
\hline 9 & $\begin{array}{c}\mathrm{CO}_{\mathbf{1 0 9}} \mathrm{CO} \\
\mathrm{CO}_{2} \mathrm{Et} \\
\end{array}$ & $\begin{array}{l}\mathbb{1}_{110}^{\mathrm{CO}_{2} \mathrm{H}} \\
\mathrm{CO}_{2} \mathrm{H}\end{array}$ & $>99 \%$ \\
\hline
\end{tabular}

\footnotetext{
a Yields are isolated yields from silica gel column chromatography based on the amounts of the diesters submitted to the reaction.

b The yield was diminished due to the slight volatility of $\mathbf{9 8 .}$
}

The mechanism remains unknown, but Niwayama has hypothesized that once one of the carboalkoxy groups is converted to a carboxylate anion, it may form micelle-like aggregates in which the hydrophobic carboalkoxy group is pointed inside and the hydrophilic $\mathrm{COO}^{-}$is pointed outside. Such an aggregate is expected to prohibit further hydrolysis by the aqueous base solution. 
Niwayama et al. conducted kinetic studies on this monohydrolysis reaction by changing the proportion of water and a typical co-solvent, and also by varying the kinds of co-solvents..$^{30,31}$ It has been found that a polar aprotic solvent that is water-miscible such as THF, MeCN and DMSO increases the reaction rates and selectivity. In the reaction mixture, the smaller amount of the co-solvent is dissolved in the larger amount of water, making one aqueous phase, and the diester participates in the reaction as the second phase, which is an organic phase, and the monohydrolysis occurs at the interface between the aqueous phase and the diester. Therefore, the monohydrolysis occurs even without a co-solvent in certain cases. The aggregates are expected to form more tightly by maximizing hydrophobic attractive interactions in the mainly aqueous media as in the hypothesis. An alcohol was observed to be a less effective co-solvent because it interferes with the aggregates formed by the hydrophobic attractive interaction of the intermediary carboxylate, also consistent with the hypothesis.

Niwayama et al. also found that $\mathrm{KOH}$ often improves selectivity and reactivity, perhaps due to the stronger affinity of $\mathrm{K}^{+}$with carbonyl oxygen, leading to the enhanced electrophilicity of the ester group. ${ }^{32}$ Based on the information from the above studies, Niwayama et al. improved the maximization of the yields from monohydrolysis of various symmetric diesters, such as dialkyl malonates, even on a mole scale. $^{33,34}$ They also modified the conditions for monohydrolysis of several bulky symmetric diesters using DMSO as a co-solvent, including diethyl esters, dipropyl esters, and dibutyl esters. ${ }^{35}$

In addition, Niwayama et al. found that in monohydrolysis of symmetric and semi-symmetric diesters having norbornene/norbornane skeletons, the relative reaction rates of the exo-ester groups are faster than those of the endo-ester groups, which are unique selectivities (Scheme 12). ${ }^{31} \quad$ Although exo/endo facial selectivities of electrophilic, nucleophilic or cyclic additions to norbornene or 2-norbornanone derivatives have been studied extensively and are known to show high exo-selectivity, no study had previously been reported for reactions that occur on the carbon that is one covalent bond away from the norbornene/norbornane ring, as the difference in the steric environment between the exo and the endo

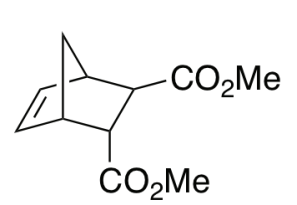

111

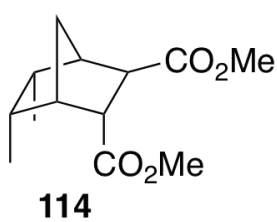

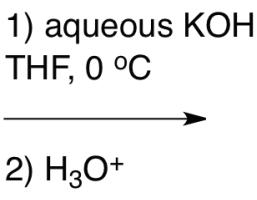

$\%$

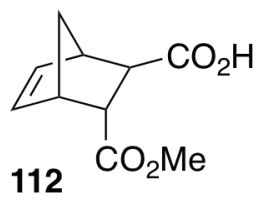

80 1) aqueous $\mathrm{KOH}$

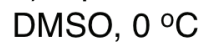

2) $\mathrm{H}_{3} \mathrm{O}^{+}$

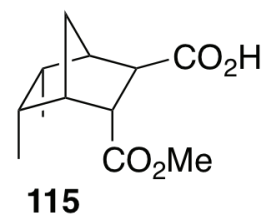

$99 \%$

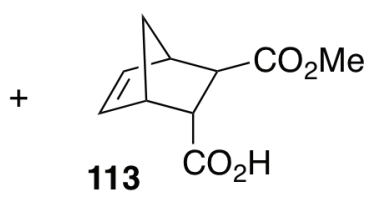

20

Scheme 12. Steric effects reported by Niwayama et al. 
direction is considered insignificant. The solvent effect described above also played a key role in maximizing the yields and selectivities in these reactions.

Although these methods do not produce enantiomerically enriched half-esters, racemic or achiral half-esters have also been widely applied to synthesis of various pharmaceuticals and polymers. For example, Wallen et al. ${ }^{36}$ and Schmidt et al. ${ }^{37}$ reported the hydrolysis of monomethyl meta-phthalate, and successfully applied it to the synthesis of the peptidomimetic prolyl oligopeptidase inhibitors and human beta-secretase. Benbrook et al. ${ }^{38}$ synthesized new cancer line inhibitors that act on head and neck, and Wagner et al. synthesized bexarotene from monomenthyl $p$-phthalate. ${ }^{39}$

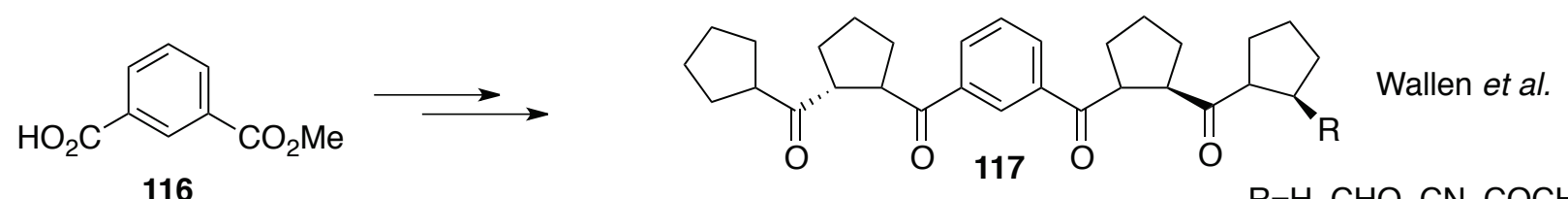

116 $\mathrm{R}=\mathrm{H}, \mathrm{CHO}, \mathrm{CN}, \mathrm{COCH}_{2} \mathrm{OH}$

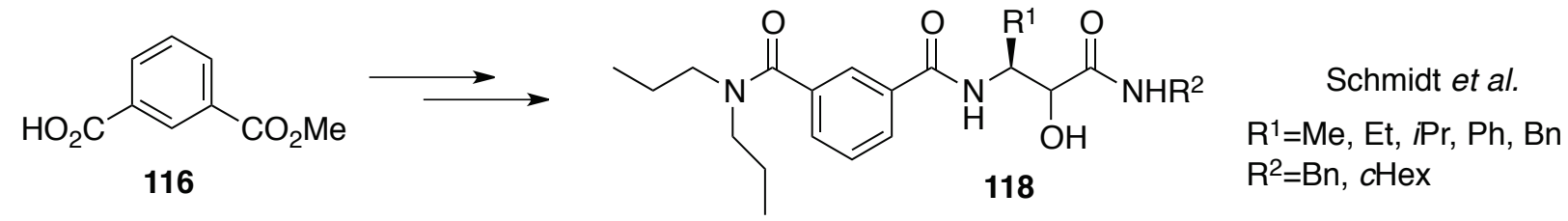<smiles>CCOCCOC(=O)c1ccc(C(=O)Oc2c(C)cc3c(c2C)C(C)(C)CC(C)(C)O3)cc1OC(=O)c1ccc(C(=O)Oc2c(C)cc3c(c2C)C(C)(C)C=C(C)O3)cc1</smiles><smiles>CC(=O)c1ccc(C(=O)O)cc1</smiles>

119

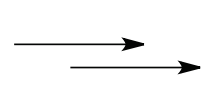<smiles>C=C(c1ccc(C(=O)O)cc1)c1cc2c(cc1C)C(C)(C)CCC2(C)C</smiles>

Wagner et al.

Scheme 13. Application of achiral half-esters

\section{4) Other methods}

The methods above rely mostly on the desymmetrization reactions of symmetric compounds. Another desymmetrization, monoesterification of dicarboxylic acids, is sometimes applied to the synthesis of half-esters, although such conversions are not as common as the monohydrolysis of diesters. Monomethylation of a near symmetric diacid, 4-bromophthalic acid, was carried out with $\mathrm{MeOH}$ in the presence of $\mathrm{TMSCl}$, producing a 1:1 mixture of regioisomeric half-esters in $94 \%$ yield in the process of the synthesis of chemokine receptor regands. ${ }^{40}$ Ogawa et al. found that some dicarboxylic acids absorbed on alumina reacted with dimethyl sulfate produce the corresponding half-esters in high selectivities as determined by GLC, GSC, or HPLC. ${ }^{41}$ The esterification of symmetric acid chlorides prepared from diacids is sometimes performed including in polymer synthesis. ${ }^{42}$ 


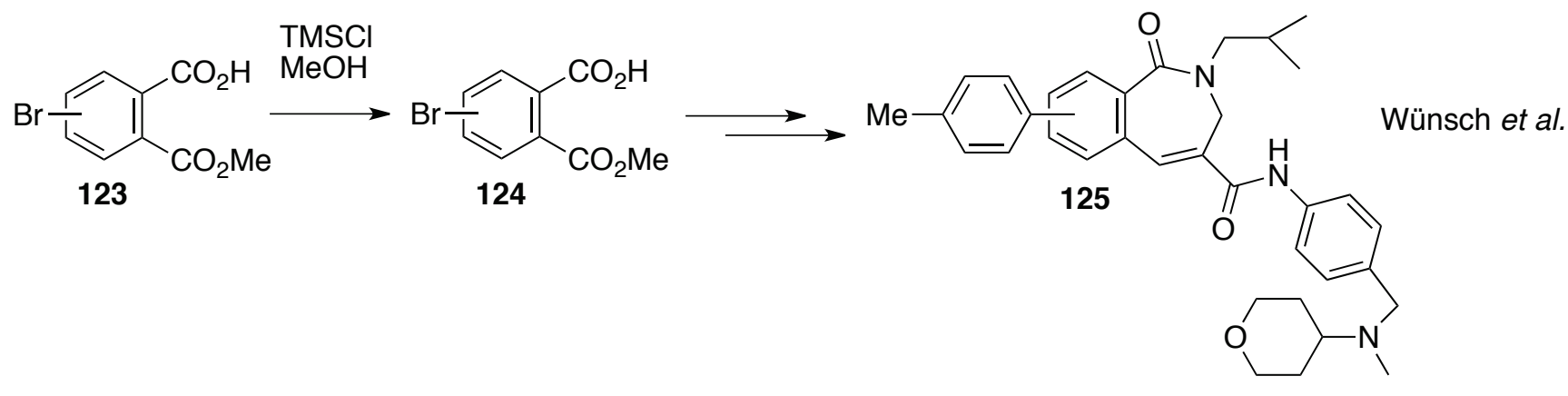

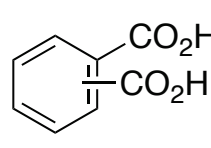

126

$$
\underset{\mathrm{n}=4,6,10}{\mathrm{HO}_{2} \mathrm{C}-\left(\mathrm{CH}_{2}\right)_{\mathrm{n}}-\mathrm{CO}_{2} \mathrm{H}} \stackrel{\mathrm{Me}_{2} \mathrm{SO}_{4}}{\underset{\mathrm{Al}_{2} \mathrm{O}_{3}}{\longrightarrow}}
$$

127<smiles>COC(=O)c1ccccc1</smiles>

128
$\mathrm{HO}_{2} \mathrm{C}-\left(\mathrm{CH}_{2}\right)_{\mathrm{n}}-\mathrm{CO}_{2} \mathrm{Me}$
$\mathrm{n}=4,6,10$

129

Ogawa et al.

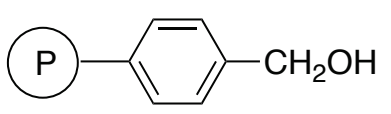

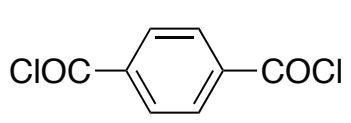

130
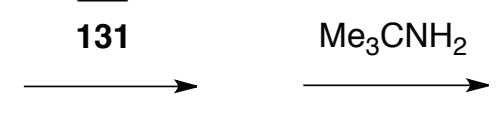

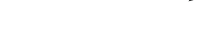

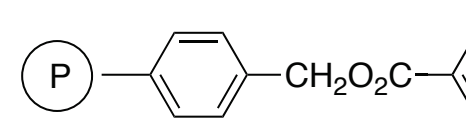

132
$\mathrm{CONHCMe}_{3}$

Leznoff et al.

Scheme 14. Application of half-esters

Without relying on desymmetrization, some interesting carboxylation reactions for the preparation of half-esters are reported. Ebert et al. studied carboxylation and subsequent esterification on the functionalized arylcopper reagents for the synthesis of half-esters. ${ }^{43}$ Ortho, meta, and para monomethyl phthalates were synthesized in this way (Scheme 15). König et al. reported carboxylation of aromatic and aliphatic bromides and triflates by visible-light $\mathrm{Ni}$ catalysis for the synthesis of some half-esters. ${ }^{44}$

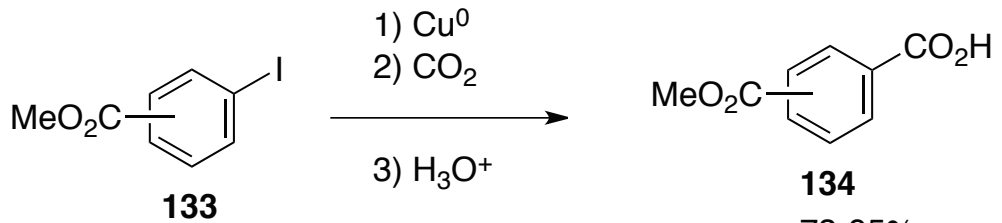

Ebert et al. $73-95 \%$

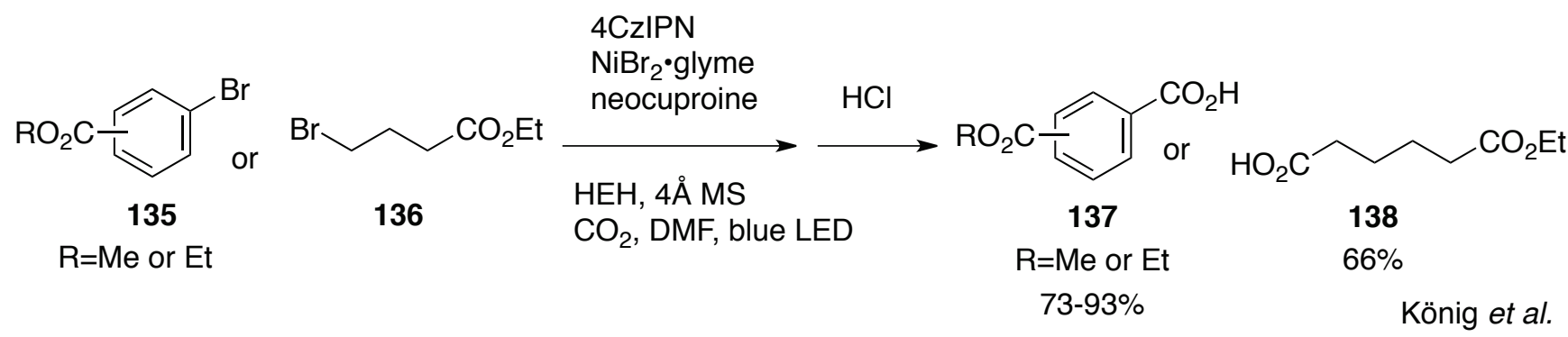

Scheme 15. Synthesis of half-esters reported by Ebert et al. and König et al. 


\section{CONCLUSIONS}

Half-esters have rather simple structures, but they have been important building blocks for synthesis of a variety of significant organic compounds. Here we have described some examples for the current development of their synthesis and applications. The starting materials for half-esters, symmetric compounds, tend to be inexpensive or inexpensively prepared on a large scale, and therefore there is no doubt in their synthetic utility. We hope that this particular specialty continues to be further developed.

\section{ACKNOWLEDGEMENTS}

We thank Kajima Foundation Research Grant for the financial support.

\section{REFERENCES}

1. For example, N. A. Chudasama, K. Prasad, and A. K. Siddhanta, Carbohydr. Polym., 2016, 151, 735; A. F. Fehervari and W. L. Grimm, J. Macromol. Sci. Pure Appl. Chem., 2002, A39, 17; J. Cavusoglu and G. Cayli, J. Appl. Polym. Sci., 2015, 132, 41457/1; S. Yamada, T. Mrozek, T. Rager, J. Owens, J. Rangel, C. G. Wilson, and J. Byers, Macromolecules, 2004, 37, 377; H.-N. Yuan, S. Li, J. Nie, Y. Zheng, and J.-A. Ma, Chem. Eur. J., 2013, 19, 15856.

2. P. K. Dubey, S. M. Mohiuddin, and R. D. Ghouse, Asian J. Chem., 1997, 9, 379.

3. G. Sabita, R. Srividya, and J. S. Yadav, Tetrahedron, 1999, 55, 4015.

4. For example, J. Hiratake, Y. Yamamoto, and J. Oda, J. Chem. Soc., Chem. Commun., 1985, 1717; J. Hiratake, M. Inagaki, Y. Yamamoto, and J. Oda, J. Chem. Soc., Perkin Trans. 1, 1987, 1053.

5. R. A. Aitken, J. Gopal, and J. A. Hirst, J. Chem. Soc., Chem. Commun., 1988, 632; R. A. Aitken and J. Gopal, Tetrahedron: Asymmetry, 1990, 1, 517.

6. C. Bolm, A. Gerlach, and C. L. Dinter, Synlett, 1999, 195; C. Bolm, I. Schiffers, C. L. Dinter, and A. Gerlach, J. Org. Chem., 2000, 65, 6984; C. Bolm, I. Schiffers, I. Atodiresei, and C. P. R. Hackenberger, Tetrahedron: Asymmetry, 2003, 14, 3455; T. Rantanen, I. Schiffers, and C. Bolm, Org. Process Res. Dev., 2007, 11, 592.

7. Y. Chen, S.-K. Tian, and L. Deng, J. Am. Chem. Soc., 2000, 122, 9542; Y. Chen and L. Deng, J. Am. Chem. Soc., 2001, 123, 11302; Y. Chen, P. McDaid, and L. Deng, Chem. Rev., 2003, 103, 2965; S.-K. Tian, Y. Chen, J. Hang, L. Tang, P. McDaid, and L. Deng, Acc. Chem. Res., 2004, 37, 621; H. Li, X. Liu, F. Wu, L. Tang, and L. Deng, Proc. Natl. Acad. Sci. USA, 2010, 107, 20625.

8. Y. Ishii, R. Fujimoto, M. Mikami, S. Murakami, Y. Miki, and Y. Furukawa, Org. Process Res. Dev., 2007, 11, 609.

9. F. Bigi, S. Carloni, R. Maggi, A. Mazzacani, G. Sartori, and G. Tanzi, J. Mol. Cat. A: Chemical, 2002, 182-183, 533. 
10. H. S. Kim, Y.-M. Song, J. S. Choi, J. W. Yang, and H. Han, Tetrahedron, 2004, 60, 12051; Y.-M. Song, J. S. Choi, J. W. Yang, and H. Han, Tetrahedron Lett., 2004, 45, 3301.

11. S. H. Oh, H. S. Rho, J. W. Lee, J. E. Lee, S. H. Youk, J. Chin, and C. E. Song, Angew. Chem. Int. Ed., 2008, 47, 7872.

12. D. Jiang, Y. Y. Wang, Y. N. Xu, and L. Y. Dai, J. Chem. Res., 2009, 167.

13. S. Y. Baek, Y. W. Kim, K. Chung, S. H. Yoo, N. K. Kim, and Y. J. Kim, Ind. Eng. Chem. Res., 2012, 41, 3564 .

14. R. Bogel-Łukasik, N. M. T. Lourenço, P. Vidinha, M. D. R. Gomes da Silva, C. A. M. Afonso, M. Nunes da Pontea, and S. Barreiros, Green Chem., 2008, 10, 243.

15. M. Ohno, Y. Ito, M. Arita, T. Shibata, K. Adachi, and H. Sawai, Tetrahedron, 1984, 40, 145.

16. K. Kamiyama, S. Kobayashi, and M. Ohno, Chem. Lett., 1987, 29.

17. K. Okano, Y. Kyotani, H. Ishihama, S. Kobayashi, and M. Ohno, J. Am. Chem. Soc., 1983, 105, 7186; K. Okano, T. Izawa, and M. Ohno, Tetrahedron Lett., 1983, 24, 217.

18. T. Iimori, Y. Takahashi, T. Izawa, S. Kobayashi, and M. Ohno, J. Am. Chem. Soc., 1983, 105, 1659.

19. S. Sano, H. Ushirogochi, K. Morimoto, S. Tamai, and Y. Nagao, Chem. Commun., 1996, 1775.

20. M. S. Yu, I. Lantos, Z.-Q. Peng, J. Yu, and T. Cacchio, Tetrahedron Lett., 2000, 41, 5647.

21. V. Iosub, A. R. Haberi, J. Leung, M. Tang, K. Vembaiyan, M. Parvez, and T. G. Back, J. Org. Chem., 2010, 75, 1612.

22. S. Baberjee, W. J. Wiggins, J. L. Geoghegan, C. T. Anthony, E. A. Woltering, and D. S. Masterson, Org. Biomol. Chem., 2013, 11, 6307.

23. Y. Namiki, T. Fujii, and M. Nakada, Tetrahedron: Asymmetry, 2014, 25, 718.

24. For example, X. Liang, A. Lohse, and M. Bols, J. Org. Chem., 2000, 65, 7432; Y. Kashima, J. Liu, S. Takenami, and S. Niwayama, Tetrahedron: Asymmetry, 2002, 13, 953; Y. Kashima, J. Liu, S. Takenami, and S. Niwayama, Bull. Chem. Soc. Jpn., 2003, 76, 831; J. Oda, M. Amano, and H. Toda, Jpn. Kokai Tokkyo Koho, 1990, JP02182198 A19900716.

25. S. Niwayama, J. Synth. Org. Chem. Jpn., 2008, 66, 983.

26. For example, E. J. Corey, J. Am. Chem. Soc., 1952, 74, 5897; A. Vecchi and G. A. Melone, J. Org. Chem., 1959, 24, 109; R. E. Strube, Org. Synth., 1963, Col. Vol. IV, 417; A. Robertson and W. F. Sandrock, J. Chem. Soc., 1933, 1617; N. De Kimpe, M. Boeykens, and K. A. Tehrani, J. Org. Chem., 1994, 59, 8215; K. Fujii and M. Komaki, Jpn. Kokai Tokkyo Koho, 1992, JP04029959; A. Makita, T. Yokota, and A. Watanabe, Jpn. Kokai Tokkyo Koho, 1990, JP02085232.

27. J. J. Duan, X. H. Song, H. Yan, and X. Q. Song, Molecules, 2011, 16, 3485.

28. D. E. Rajsfus, P. Gilinsky-Sharon, and A. A. Frimer, J. Fluorine Chem., 2013, 148, 59.

29. S. Niwayama, J. Org. Chem., 2000, 65, 5834. 
30. S. Niwayama, H. Wang, Y. Hiraga, and J. C. Clayton, Tetrahedron Lett., 2007, 48, 8508.

31. S. Niwayama, H. Cho, M. Zabet-Moghaddam, and B. R. Whittlesey, J. Org. Chem., 2010, 75, 3775; S. Niwayama and Y. Hiraga, Tetrahedron Lett., 2003, 44, 8567.

32. S. Niwayama and A. Rimkus, Bull. Chem. Soc. Jpn., 2005, 78, 498.

33. S. Niwayama, H. Cho, and C. Lin, Tetrahedron Lett., 2008, 49, 4434.

34. S. Niwayama and H. Cho, Chem. Pharm. Bull., 2009, 57, 508.

35. J. Shi and S. Niwayama, Tetrahedron Lett., 2018, 59, 799.

36. E. A. Wallén, J. A. M. Christiaans, M. M. Forsberg, J. I. Venäläinen, P. T. Männistö, and J. Gynther, J. Med. Chem., 2002, 45, 4581 .

37. S. Umbreen, M. Brockhaus, H. Ehrenberg, and B. Schmidt, Eur. J. Org. Chem., 2006, 4585.

38. D. Zacheis, A. Dhar, S. Lu, M. M. Madler, J. Klucik, C. W. Brown, S. Liu, F. Clement, S. W. Subramanian, G. M. Weerasekare, K. D. Berlin, M. A. Gold, J. R. Houck, K. R. Fountain, and D. M. Benbrook, J. Med. Chem., 1999, 42, 4434.

39. C. E. Wagner, P. W. Jurutka, P. A. Marshall, T. L. Groy, A. Vaart, J. W. Ziller, J. K. Furmick, M. E. Graeber, E. Matro, B. V. Miguel, I. T. Tran, J. Kwon, J. N. Tedeschi, S. Moosavi, A. Danishyar, J. S. Philp, R. O. Khamees, J. N. Jackson, D. K. Grupe, S. L. Badshah, and J. W. Hart, J. Med. Chem., 2009, 52, 5950 .

40. S. Thum, A. K. Kokornaczyk, T. Seki, M. De Maria, N. V. O. Zacarias, H. de Vries, C. Weiss, M. Koch, D. Schepmann, M. Kitamura, N. Tschammer, L. H. Heitman, A. Junker, and B. Wünsch, Eur. J. Med. Chem., 2017, 135, 401.

41. H. Ogawa, Y. Ichimura, T. Chihara, S. Teratani, and K. Taya, Bull. Chem. Soc. Jpn., 1986, 59, 2481; H. Ogawa, T. Chihara, and K. Taya, J. Am. Chem. Soc., 1985, 107, 1365.

42. J. M. Goldwasser and C. C. Leznoff, Can. J. Chem., 1978, 56, 1562; S. Bhattacharjee, C. Gong, J. W. Jones, and H. W. Gobson, Polymer, 2015, 81, 99.

43. G. W. Ebert, W. L. Juda, R. H. Kosakowski, B. Ma, L. Dong, K. E. Cummings, M. V. B. Phelps, A. E. Mostafa, and J. Luo, J. Org. Chem., 2005, 70, 4314.

44. Q.-Y. Meng, S. Wang, and B. König, Angew. Chem. Int. Ed., 2017, 56, 13426. 

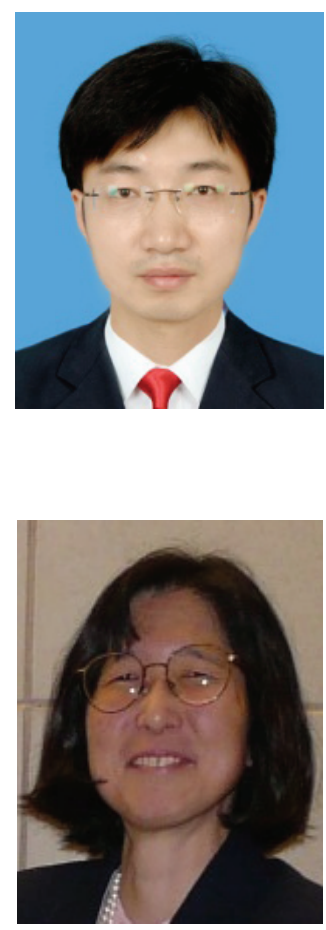

Dr. Jianjun Shi obtained a Masters degree in Applied Chemistry in 2013 from Hainan University, Haikou, China. Afterwards, he worked for the Jiuquan Food and Drug Administration, Gansu province in China, as a project assistant on the Drug Risk Management Board from 2013 to 2015. In 2015, he joined Prof. Satomi Niwayama's laboratory at Muroran Institute of Technology, Japan. He received his Ph. D. degree under the guidance of Professor Niwayama in 2018. Recently, he has been working at the Key Laboratory of Tropical Medicinal Chemistry Plant of the Ministry of Education, College of Chemistry and Chemical Engineering, Hainan Normal University, China. His research interests are asymmetric syntheses and macromolecular polymerization in the field of synthetic organic chemistry.

Professor Satomi Niwayama received her Ph. D. from the Department of Pharmaceutical Sciences, University of Tokyo, Japan, specializing in synthetic organic chemistry in 1989. After postdoctoral appointments with Professor Leo A. Paquette at the Ohio State University, USA, Professor Kendall N. Houk at the University of California, Los Angeles, USA, and Professor Jun O. Liu at Massachusetts Institute of Technology, USA, in 1989-1998, Professor Niwayama assumed a position as Assistant Professor in the Department of Chemistry, Oklahoma State University, USA in 1998. She then became an Associate Professor in the Department of Chemistry and Biochemistry, Texas Tech University, USA in 2004. She has been a Professor at Muroran Institute of Technology, Japan, since 2014. Among the awards and honors Professor Niwayama received are the Southwest Region American Chemical Society Award, the American Chemical Society PROGRESS/Dreyfus Lectureship Award, the National Science Foundation-CAREER Award, the Japanese Society for Process Chemistry Award for Excellence, the Banyu Award in Synthetic Organic Chemistry, and the Morita Science Research Promotion Award. 